Terbit online pada laman : https://teknosi.fti.unand.ac.id/

Jurnal Nasional Teknologi dan Sistem Informasi

ISSN (Print) 2460-3465 | ISSN (Online) 2476-8812 |

Artikel Penelitian

\title{
Analisis Keberhasilan Enterprise Resource Planning Menggunakan Model DeLone and McLean Tingkat Individual
}

\author{
Mochamad Rizky Ilmawan ${ }^{a}$, Vera Pujani ${ }^{a}{ }^{*}$ \\ ${ }^{a}$ Program Studi Manajemen, Fakultas Ekonomi, Universitas Andalas, Padang, 25162, Indonesia
}

\section{INFORMASI ARTIKEL}

Sejarah Artikel:

Diterima Redaksi: 12 Desember 2019

Revisi Akhir: 08 Juni 2020

Diterbitkan Online: 10 Juni 2020

\section{KATA KUNCI}

Enterprised Resource Planning SAP,

Model Kesuksesan Sistem Informasi

\section{KORESPONDENSI}

E-mail: verapujani@eb.unand.ac.id

\section{A B $\mathbf{S}$ T $\mathbf{R}$ A $\mathbf{C}$ T}

Saat ini organisasi sangat bergantung pada sistem informasi untuk meningkatkan kinerja mereka dan tetap kompetitif. Begitu pula dengan perusahaan manufaktur, sebagai sebuah organisasi yang memiliki bisnis proses yang sangat besar perlu mengimplementasikan ERP (Enterprise Resource Planning) dari SAP. Pengukuran keberhasilan atau efektivitas sistem informasi (SI) sangat penting untuk menilai dan keefektifan tindakan manajemen IS dan investasi IS. Analisis keberhasilan SI dilakukan dengan DeLone dan McLean's sistem informasi sukses model yang memiliki enam dimensi dalam kerangka kerjanya yaitu: information quality (kualitas informasi), system quality (kualitas sistem), service quality (kualitas layanan), extended use (pengembangan penggunaan), user satisfactory (kepuasan user), dan individual benefit (manfaat individu). Penelitian ini menggunakan metode penelitian kuantitatif dan survei terhadap 239 karyawan sebuah perusahaan manufaktur yang ada di Kota Padang. Data yang diperoleh diolah menggunakan Structural Equation Modeling (SEM) dengan menggunakan software AMOS. Hasil dari penelitian ini menunjukkan model penelitian yang diajukan memiliki kesesuaian yang baik dengan data. Kemudian dari delapan (8) hipotesis yang diuji, seluruh hipotesis tersebut didukung oleh data yang diteliti menunjukkan bahwa semua dimensi berpengaruh secara signifikan terhadap penggunaan individu.

\section{PENDAHULUAN}

\subsection{Latar Belakang}

Untuk beroperasi, sebuah organisasi harus berurusan dengan banyak informasi. Sistem informasi memungkinkan perusahaan untuk mengelola semua informasi mereka, membuat keputusan yang lebih baik, dan meningkatkan pelaksanaan proses bisnis mereka [1]. Begitu pula perusahaan yang memiliki bisnis proses yang sangat komplek memerlukan sistem informasi untuk dapat menangani bisnis proses dimana supaya perusahaan dan industri terus berkembang dengan cepat. Untuk itu perusahaan perlu mengimplementasikan aplikasi enterprise atau lebih dikenal dengan ERP (Enterprise Resource Planning) dari SAP untuk membantu bisnis menjadi lebih fleksibel, produktif, [1] dan menghasilkan kinerja lebih tinggi [2]. Perusahaan yang diteliti ini pada 2008 telah sukses mengimplementasikan ERP SAP, namun keberhasilan sistem ERP SAP berbeda dengan keberhasilan implementasi ERP SAP dimana sukses sistem ERP yaitu pemanfaatan sistem untuk mencapai efektivitas organisasi atau sejauh mana sistem informasi benar-benar berkontribusi untuk mencapai tujuan organisasi [3].

ERP SAP merupakan salah satu biaya yang sangat besar sehingga harus diperhitungkan juga manfaat ERP bagi perusahaan. Investasi implementasi ERP merupakan investasi yang sangat mahal yaitu menghabiskan biaya antara setengah juta dolar hinggal $\$ 300$ juta, dengan rata-rata biaya adalaha $\$ 15$ juta atau Rp 210 milyar [4]. Pengukuran keberhasilan atau efektivitas sistem informasi (IS) sangat penting untuk pemahaman kita tentang nilai dan keefektifan tindakan manajemen IS dan investasi IS [5]. Pada penelitian ini, akan digunakan DeLone dan McLean's sistem informasi sukses model (D\&M IS success model; Delone and Mclean's, 1992, 2003) untuk menganalisa tingkat keberhasilan dari penerapan SAP ERP. Model ini telah digunakan pada penelitian lain seperti e-commerce [6,7], construction [8], healthcare [9], dan seperti yang akan diteliti yaitu pada ERP $[10,5,11]$. DeLone dan McLean's sistem informasi sukses 
model memiliki enam dimensi dalam kerangka kerjanya yaitu: kualitas informasi (information quality), system quality (kualitas sistem), service quality (kualitas layanan), intention to use (kemauan user menggunakan), user satisfactory (kepuasan user), dan net benefit (keuntungan) [12]. Model Keberhasilan D\&M IS adalah yang paling banyak dikutip dan telah memberikan kontribusi berharga bagi pemahaman kita tentang keberhasilan SI [3].

Dari uraian sebelumnya, ada beberapa permasalahan yang dapat dirumuskan yaitu:

1.Bagaimana hubungan antara Kualitas Sistem terhadap Kepuasan Pengguna?

2.Bagaimana hubungan antara Kualitas Informasi terhadap Kepuasan Pengguna?

3.Bagaimana hubungan antara Kualitas Layanan terhadap Kepuasan Pengguna?

4.Bagaimana hubungan antara Kualitas Sistem terhadap Pengembangan?

5.Bagaimana hubungan antara Kualitas Informasi terhadap

Pengembangan penggunaan?

6.Bagaimana hubungan antara Kualitas Layanan terhadap

Pengembangan penggunaan?

7.Bagaimana hubungan antara Kepuasan Pengguna terhadap kesuksesan SI ERP pada level individual (karyawan)?

8.Bagaimana hubungan antara Pengembangan penggunaan terhadap kesuksesan SI ERP pada level individual (karyawan)?

Menurut Brown [13], sistem ERP adalah seperangkat aplikasi bisnis terintegrasi, atau modul yang menjalankan fungsi bisnis umum seperti akuntansi buku besar, hutang dagang, piutang dagang, perencanaan kebutuhan material, manajemen pesanan, kontrol inventaris, dan manajemen sumber daya manusia. Untuk mengimplementasikan sistem ERP, sebuah perusahaan berkomitmen untuk mengubah proses bisnisnya agar sesuai dengan yang tertanam dalam paket perangkat lunak [13]. Lebih dari 85 persen chief information officer (CIO)setuju atau sangat setuju bahwa sistem ERP mereka sangat penting bagi inti bisnis mereka [14]. Perusahaan yang diteliti ini menggunakan ERP SAP yang merupakan perangkat lunak perusahaan standar untuk integrasi real-time dari semua proses bisnis [15]. SAP merupakan ERP berkualitas yang menawarkan lebih dari 95.000 pelanggan di lebih dari 120 negara [13].

Sebagian besar studi atau penelitian meneliti mengenai performa ERP pasca-implementasi melakukan pengujian terhadap ERP pascaimplementasi di tingkat perusahaan dan sedikit penelitian yang memfokuskan pada ERP pasca implementasi di tingkat individu [5]. Padahal untuk mendapatkan hasil penurunan biaya yang dijanjikan tersebut perusahaan harus mengeluarkan biaya yang besar dan sumber daya manusia yang baik [14]. Selaini itu karyawan yang puas dengan sistem ERP lebih cenderung produktif [16]. Kepuasan pengguna dapat diartikan sebagai konsekuensi dari keberhasilan" IS dalam mengadopsi organisasi dan bukan bagian dari dimensi kesuksesan [3].

DeLone and McLean Information System (IS) Success Model merupakan sebuah framework dan model untuk mengukur variable bebas yang komplek dalam penelitian Sistem Informasi (IS) [12].
Pada tahun 2002 dilakukan update pada model DeLone dan McLean IS success model ditunjukkan pada Gambar 1 di bawah ini.

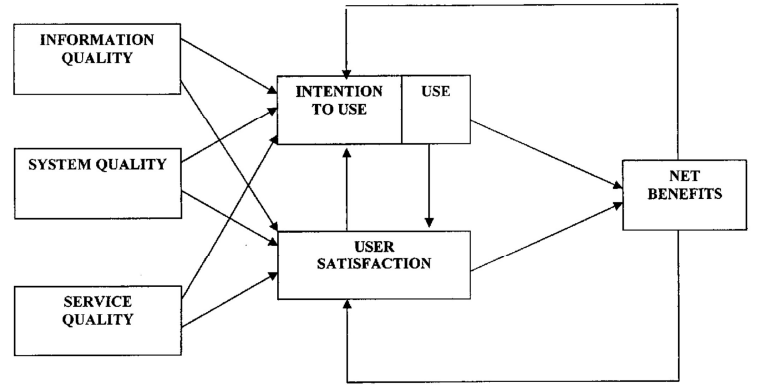

Gambar 1. DeLone and McLean Information System Success Model Update 2003.

Penelitian ini dilakukan untuk melakukan analisis terhadap manfaat individu (individual benefit) dimana pada beberapa pengujian menunjukkan adanya hubungan seperti: 1 . hubungan penggunaan sistem (system use) dengan dampak individual (individual impact), 2. kualitas sistem (system quality) dengan dampak individual (individual impact), 3 kualitas informasi (information quality) dan dampak individu (individual impact) [12]. Dengan adanya penelitian tersebut maka semakin menguatkan untuk dapat dilakukan penelitian ini.

\subsection{Pengembangan Hipotesis}

Berdasarkan model yang ada pada Delone and Mc Lean Information System Success Model dan beberapa penelitian terdahulu didapatkan beberapa hipotesis sebagai berikut.

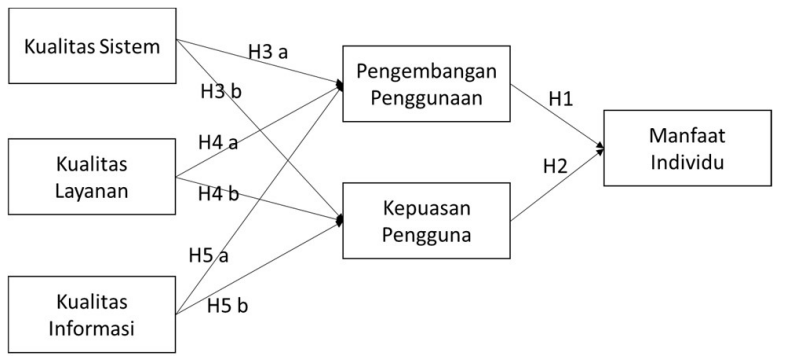

Gambar 2. Sukses Model Penelitian

Banyak peneliti menyarankan bahwa penggunaan (use) atau jumlah penggunaan pada model DM asli tidak digunakan dalam analisis ERP atau aplikasi wajib $[3,5,11]$. Pengembangan penggunaan adalah ukuran yang tepat karena mempertimbangkan unsur-unsur konteks sistem (yaitu, luasnya penggunaan) dan konteks tugas (yaitu, berbagai penggunaan dalam tugas yang berbeda) dalam mengonseptualisasikan penggunaan sistem [24]. Pengguna dapat menemukan fitur berguna tambahan dan menerapkannya pada pekerjaan mereka, akibatnya mereka dapat menerima manfaat penuh dari sistem ERP [7]. Artinya, dengan melampaui penggunaan rutin sistem, karyawan memiliki kesempatan untuk mengeksploitasi potensi terkaya sistem untuk mendukung pekerjaan mereka, sehingga menghasilkan produktivitas dan kinerja yang lebih tinggi [25]. Oleh karena itu, penelitian ini menghipotesiskan bahwa 
Hipotesis 1 (H1): Terdapat hubungan positif antara Pengembangan Penggunaan ERP SAP terhadap manfaat individu pengguna.

Kepuasan pengguna mengacu pada respon penerima terhadap penggunaan output dari sistem informasi, atau sejauh mana pengguna merasa IS memenuhi persyaratan mereka [12]. Kepuasan adalah konsekuensi dari pengalaman pengguna selama tahap-tahap gairah kebutuhan, pencarian informasi, evaluasi alternatif, keputusan pembelian, dan perilaku pasca-pembelian [26]. Bukti dalam literatur menunjukkan bahwa penggunaan sistem, meskipun wajib, tidak cukup untuk menerima manfaat sistem [16,27]. Sebaliknya, karyawan ERP yang puas lebih cenderung produktif, terutama di mana penggunaan sistem tersebut wajib [16]. Oleh karena itu, penelitian ini menghipotesiskan bahwa:

Hipotesis 2 (H2): Terdapat hubungan positif antara kepuasan pengguna terhadap manfaat individu pengguna

Kualitas sistem mengacu pada ukuran sistem pemrosesan informasi itu sendiri yaitu, kualitas kinerja IS dari perspektif teknis [3, 12]. Jika pengguna mengalami sistem yang stabil, seperti aksesibilitas dan keandalan, dan merasakan sistem ERP membantu menyelesaikan pekerjaan dengan lebih baik, pengguna lebih cenderung memperluas penggunaan fungsi dan fitur sistem [5]. Selain itu, baik model keberhasilan D\&M IS [12] dan penelitian sebelumnya (misalnya [28, $29,27])$ menyarankan hubungan positif antara kualitas sistem dan kepuasan pengguna, Dari landasan penelitian tersebut hipotesis yag muncul:

Hipotesis 3a (H3a) : Kualitas sistem ERP SAP yang lebih baik berpengaruh positif terhadap tingkat pengembangan penggunaan.

Hipotesis 3b (H3b): Kualitas sistem ERP SAP yang lebih baik berpengaruh terhadap positif tingkat kepuasan pengguna yang lebih tinggi.

Service Quality/ServQ (kualitas layanan) mengacu pada dukungan keseluruhan yang ditawarkan oleh penyedia layanan [12]. Hsieh et al. [25] menemukan bahwa penggunaan yang diperluas, dalam konteks menggunakan sistem manajemen hubungan pelanggan (CRM), memiliki hubungan yang signifikan dengan ServQ yang dinilai oleh pelanggan mereka. Dengan memiliki personel layanan SI yang memberikan ServQ baik pengguna mungkin merasa terdorong untuk belajar dan mencoba lebih banyak fungsi yang tersedia dari sistem yang diterapkan [5]. Interaksi positif dengan personel IS juga dapat meningkatkan pengalaman yang lebih memuaskan ketika menggunakan sistem wajib $[30,31]$. Oleh karena itu hipotesis penelitian ini adalah:

Hipotesis 4a (H4a): Kualitas layanan sistem ERP yang lebih baik berpengaruh positif terhadap pengembangan penggunaan.

Hipotesis 4b (H4b): Kualitas layanan sistem ERP yang lebih baik berpengaruh positif terhadap tingkat kepuasan pengguna yang lebih tinggi
Information quality (IQ) mengacu pada ukuran output sistem informasi yaitu, kualitas informasi yang dihasilkan sistem, terutama dalam bentuk laporan atau layar [3, 12]. Ketika pengguna melihat bahwa informasi itu akurat, diperbarui, konsisten, relevan, lengkap, dan formatnya mudah dimengerti, itu akan mengarahkan mereka ke tingkat penggunaan yang lebih tinggi dan tingkat kepuasan yang lebih tinggi [5]. Sehingga hipotesis dari penelitian ini adalah:

Hipotesis 5a (H5a): Kualitas informasi ERP SAP yang lebih tinggi berpengaruh positif terhadap tingkat pengembangan penggunaan yang lebih tinggi.

Hipotesis 5b (H5b): Kualitas informasi ERP SAP yang lebih tinggi berpengaruh positif terhadap tingkat kepuasan pengguna yang lebih tinggi.

\section{METODE PENELITIAN}

Penelitian yang dilakukan ini dilihat dari tujuannya bersifat penelitian testing thoery (explanatory research), dengan metode penelitian kuantitatif. Penelitian ini digunakan untuk menguji hipotesis sebelumnya dengan mengukur hubungan antar variable, data dianalisis menggunakan teknik statistic bernama Struktural Equation Modeling (SEM) [17]. Jenis data yang digunakan adalah data primer parametrik, dimana data penelitian yang didapatkan dengan langsung kepada sumber data yang ingin dikumpulkan.

Penelitian ini dilakukan dengan metode pengumpulan data yaitu berupa pembagian kuesioner kepada responden. Populasi dalam penelitian ini merupakan karyawan yang bekerja di Perusahaan yang sedang diteliti dan menggunakan ERP SAP. Adapun teknik sampling yang akan dipakai adalah dengan teknik convenience sampling dimana satu-satunya kriterianya adalah apakah peserta setuju untuk berpartisipasi [18]. Sesuai dengan model pada penelitian ini sampel minimal yang dibutuhkan dalam penelitian ini menurut Hair [19] yaitu 150 sample, namun menurut Rosenberg [20] sampel dengan jumlah +/- 250 lebih dianjurkan. Sehingga pada akhir penelitian ini didapatkan jumlah sampel sebanya 239 responden yang merupakan karyawan pengguna ERP SAP. Definisi operasionalisasi variabel dalam penelitiannya ini terdiri dari 3 variabel eksogen (KS, KI, KL) 2 variabel eksogen endogen (KP, PP), dan 1 variabel endogen (IB).

Teknik yang dipilih untuk menganalisis dan menguji penelitian ini adalah Structural Equation Modeling (SEM) dengan menggunakan software AMOS (Analysis of Moment Structures). Penggunaan AMOS dikarenakan AMOS adalah modul SPSS tambahan, dan secara khusus digunakan untuk Pemodelan Persamaan Struktural (SEM), path analysis, dan confirmatory factor analysis. Dengan pemodelan persamaan structural (Structural Equation Modeling / SEM) ini dapat diperiksa serangkaian hubungan ketergantungan secara bersamaan sehingga sangat berguna dalam menguji teori yang berisi banyak persamaan yang melibatkan hubungan ketergantungan [19]. Persamaan ini menggambarkan semua hubungan di antara konstruksi (variabel dependen dan independen) yang terlibat dalam analisis [19]. 
Dengan SEM peneliti dapat menentukan kombinasi hubungan yang memiliki dukungan teoritis untuk pertanyaan penelitian yang ada [19, 21].

Statistik deskriptif dalam penelitian ini antara lain: penyiapan data dalam bentuk tabel, grafik, perhitungan median, mean, standar deviasi, perhitungan persentase, dan lain-lain [22]. Semua konstruksi penelitian yang termasuk dalam penelitian ini memiliki skala multiitem dimana setiap item dalam survei menggunakan skala Likert 5 poin $(1=$ sangat tidak setuju, $5=$ sangat setuju $)$.

Validitas model pengukuran penelitian ini tergantung pada dua hal yaitu: (1) membangun tingkat goodness-of-fit (GOF) yang dapat diterima untuk model pengukuran dan (2) menemukan bukti spesifik validitas konstruk dengan melakukan confirmation factor analysis (CFA) [19]. GOF akan diuji dengan menggunakan chi-square $(\chi 2) /$ derajat kebebasan (df), Root Mean Square Error of Approximation (RMSEA), GFI, RMR, NNFI (TLI), CFI dan Hoelter Index. Sedangka CFA akan diukur dari factor loading, Average Variance Extracted (AVE), Reliability (CR), dan Discriminant validity [19].

Untuk menguji hipotesis diidentifikasi masing-masing hubungan jalur. Jika model menunjukkan kecocokan yang baik, dan jika jalur yang dihipotesiskan signifikan dan sesuai dengan arah yang dihipotesiskan (H1, H2, dan Hn positif), maka model didukung [19]. Hipotesis terdukung atau diterima apabila t-statistic lebih tinggi dibandingkan nilai t-table atau dapat juga dengan membandingkan pvalue dengan nilai $\alpha$ yang dipergunakan. Nilai t-table untuk hipotesis satu ekor (one-tailed) dengan tingkat keyakinan 95 persen $(\alpha=0,05)$ adalah 1,647 [23]

\section{HASIL}

Penelitian ini mengadopsi kerangka kerjar model Delone and Mc Lean Information System Success Model. Beberapa variabel digunakan namun terdapat beberapa variabel dan hubungan yang dimodifikasi. Variabel yang dimodifikasi yang pertama adalah individual benefit sesuai dengan tujuan penelitian ini untuk menganalisis kesuksesan ERP pada level individu. Kemudian variabel pengembangan penggunaan extended use lebih disukai untuk implementasi SI yang bersifat wajib [5, 24]. Sehingga model yang akan diajukan oleh penelitian ini ada pada Gambar 3.1 berikut.

\subsection{Profil Responden (ini hasil penelitian)}

Dari 300 kuesioner yang telah didistribusikan didapat 239 data atau $79,6 \%$ yang dapat diolah. Tahapan yang dilalui dalam penelitian, pembangunan konsep, atau penyelesaian kasus, dituliskan pada bagian metodologi. Berdasarkan hasil dari data kuisioner penelitian yang telah dilakukan, maka dapat dijabarkan profil deskriptif responden berdasarkan departemen tempat karyawan bekerja, tingkat esselon karyawan, masa kerja karyawan, lama karyawan menggunakan SAP, serta frekwuensi karyawan dalam menggunakan SAP ditunjukkan oleh Tabel 1.
Dari Table 1 di atas mengenai gambaran secara umum responden diketahui beberapa gambaran responden antara lain: 1. bahwa ratarata responden adalah karyawan yang sering memanfaatkan SAP dalam setiap pekerjaannya, 2. Prosentase terbesar responden penelitian ini adalah eselon 5 dengan frekuensi 93 kuisioner terisi atau $38,9 \%, 3$. Rata-rata responden merupakan karyawan yang sudah lama menggunakan SAP, sehingga data yang didapatkan dapat menggambarkan data yang benar, 4. mayoritas responden adalah karyawan yang sangat memahami SAP sesuai dengan jumlah frekuensi responden dalam menggunakan SAP dalam pekerjaannya.

\begin{tabular}{|c|c|c|}
\hline Departemen & Frekuensi & Percent \\
\hline Distrans & 1 & .4 \\
\hline GRC & 2 & .8 \\
\hline ICT & 2 & .8 \\
\hline Internal Aud & 7 & 2.9 \\
\hline Keuangan & 23 & 9.6 \\
\hline Pemeliharaan & 71 & 29.7 \\
\hline Pengadaan & 5 & 2.1 \\
\hline Penjualan & 18 & 7.5 \\
\hline Perencanaan & 60 & 25.1 \\
\hline Produksi Kli & 25 & 10.5 \\
\hline Produksi Sem & 23 & 9.6 \\
\hline$\underline{\mathrm{SDM}}$ & 2 & .8 \\
\hline Total & 239 & 100.0 \\
\hline Eselon & Frekuensi & Percent \\
\hline 1 & 4 & 1.7 \\
\hline 2 & 12 & 5.0 \\
\hline 3 & 60 & 25.1 \\
\hline 4 & 70 & 29.3 \\
\hline 5 & 93 & 38.9 \\
\hline Total & 239 & 100.0 \\
\hline Masa Penggunaan & Frekuensi & Percent \\
\hline Kurang dari 2 tahun & 14 & 5.9 \\
\hline $2-5$ tahun & 66 & 27.6 \\
\hline $6-8$ tahun & 70 & 29.3 \\
\hline Lebih dari 8 tahun & 89 & 37.2 \\
\hline Total & 239 & 100.0 \\
\hline Frekuensi Penggunaan & Frekuensi & Percent \\
\hline Setiap hari & 209 & 87.4 \\
\hline Tiga kali seminggu & 11 & 4.6 \\
\hline Sekali Seminggu & 8 & 3.3 \\
\hline Lainnya & 11 & 4.6 \\
\hline Total & 239 & 100.0 \\
\hline
\end{tabular}

\subsection{Analisa Deskripsi Variabel Penelitian}

Analisa deskripsi variable digunakan untuk mengetahui tanggapan responden terhadap kualitas informasi, kualitas sistem, kualitas layanan ERP SAP yang digunakan oleh karyawan. Selain itu juga dilakukan analisa deskriptif terhadap variable kepuasan pengguna, pengembangan penggunaan, dan keuntungan individu yang dirasakan oleh karyawan pengguna ERP SAP.

Tabel 2. Deskripsi Variabel

\begin{tabular}{lll}
\hline Variabel & Mean & Std Dev \\
\hline Kualitas Sistem (KS) & 4,04 & 0,714 \\
Kualitas Informasi (KI) & 4,06 & 0,691 \\
Kualitas Layanan (KL) & 3,92 & 0,740 \\
Kepuasan Pengguna (KP) & 4,07 & 0,632 \\
Pengembangan Penggunaan (PP) & 4,07 & 0,601 \\
Individual Benefit (IB) & 4,05 & 0,621 \\
\hline
\end{tabular}


Dari Tabel 2 seluruh variabel menunjukkan bahwa rata-rata responden setuju bahwa faktor kesuksesan ERP SAP di Perusahaan sudah baik.

\subsection{Analisis Konfirmasi Faktor (CFA)}

Analisis Konfirmasi Faktor (Confirmatory Factor Analysis /CFA) digunakan untuk menguji apakah semua indikator variabel yang telah diukur sesuai atau cocok dengan variabel konsturuksinya dan menganalisis goodness-of-fit yang dapat diterima untuk model pengukuran. Pada tahap ini dilakukan analisis untuk menemukan bukti spesifik validitas konstruk dengan melakukan confirmation factor analysis (CFA). Untuk itu pada AMOS dibuat sebuah model untuk mengukur kovarian dari setiap konstruk laten seperti yang ditunjukkan oleh Gambar 3 di bawah ini.

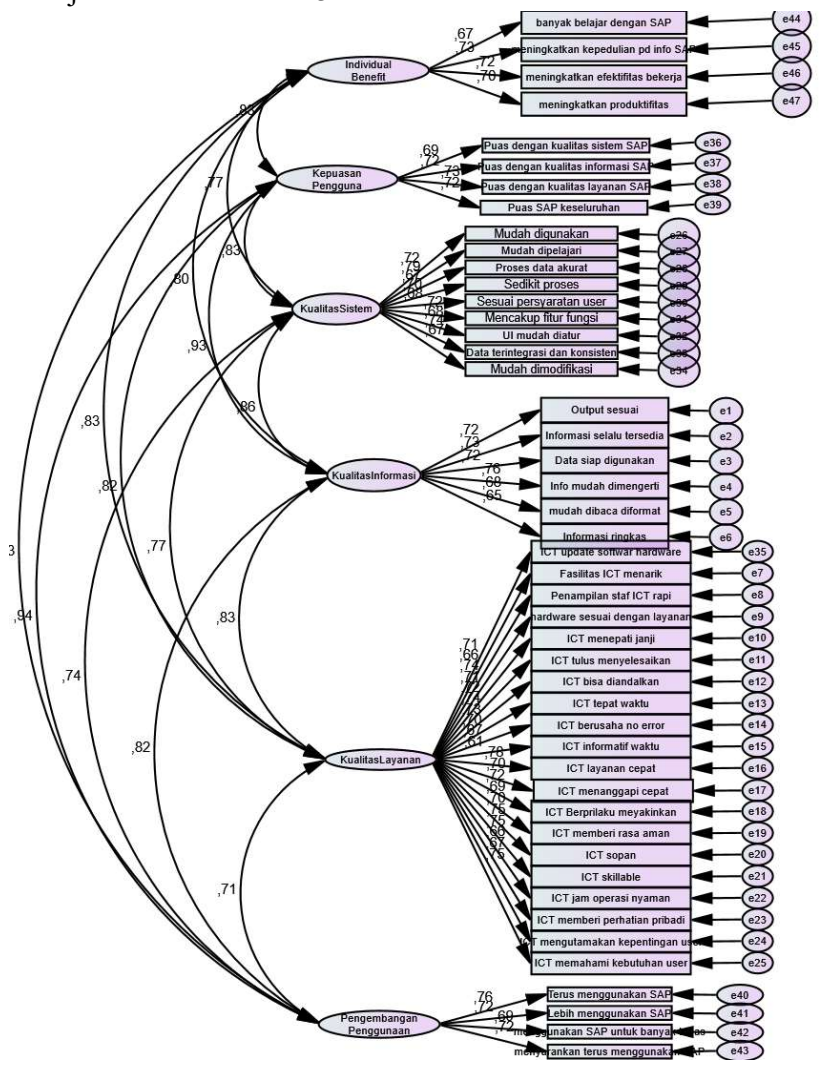

Gambar 3. Model Covarian AMOS

Dari hasil perhitungan AMOS didapatkan nilai faktor loading seperti yang ditunjukkan oleh Tabel 3. Dari Tabel 3 diketahui bahwa hasil perhitungan factor loading yang dilakukan oleh AMOS menunjukkan bahwa ada beberapa indicator yang memiliki factor loading $<=0,6$ sehingga harus dihilangkan dari model. Adapun beberapa indicator yang harus dihilangkan yaitu KI 6, KL 10, KS1 dan KS9.

Setelah indicator yang tidak memenuhi factor loading tersebut dibuang, maka didapatkan faktor loading yang memenuhi syarat yaitu bernilai $>0,6$. Kemudian Construct Realibility (CR) dari setiap variabel $>0.7$ atau dapat dikatakan bahwa seluruh variabel atau construk pada model ini reliable terhadap indikatornya. Selain itu nilai
Average Variance Extracted (AVE) pada setiap variabel bernilai 0.5 atau sudah bersifat konvergen.

Tabel 3. Hasil factor loading, uji realibilitas, uji validitas

\begin{tabular}{|c|c|c|c|c|}
\hline Variabel & Indikator & Loading & AVE & $\mathrm{CR}$ \\
\hline \multirow{4}{*}{$\begin{array}{l}\text { Individual_Ben } \\
\text { efit }\end{array}$} & IB1 & 0,681 & 0,5 & 0,79 \\
\hline & IB2 & 0,736 & & \\
\hline & IB3 & 0,674 & & \\
\hline & IB4 & 0,686 & & \\
\hline \multirow{6}{*}{$\begin{array}{l}\text { KualitasInforma } \\
\text { si }\end{array}$} & KI1 & 0,686 & 0,5 & 0,83 \\
\hline & $\mathrm{KI} 2$ & 0,664 & & \\
\hline & $\mathrm{KI} 3$ & 0,715 & & \\
\hline & KI4 & 0,686 & & \\
\hline & KI5 & 0,678 & & \\
\hline & KI6* & 0,609 & & \\
\hline \multirow{20}{*}{$\begin{array}{l}\text { KualitasLayana } \\
\mathrm{n}\end{array}$} & KL1 & 0,627 & 0,5 & 0,9 \\
\hline & KL10* & 0,498 & & \\
\hline & KL11 & 0,725 & & \\
\hline & KL12 & 0,67 & & \\
\hline & KL13 & 0,707 & & \\
\hline & KL14 & 0,642 & & \\
\hline & KL15 & 0,713 & & \\
\hline & KL16 & 0,746 & & \\
\hline & KL17 & 0,752 & & \\
\hline & KL18 & 0,648 & & \\
\hline & KL19 & 0,682 & & \\
\hline & KL2 & 0,642 & & \\
\hline & KL20 & 0,728 & & \\
\hline & KL3 & 0,737 & & \\
\hline & KL4 & 0,721 & & \\
\hline & KL5 & 0,703 & & \\
\hline & KL6 & 0,721 & & \\
\hline & KL7 & 0,72 & & \\
\hline & KL8 & 0,719 & & \\
\hline & KL9 & 0,696 & & \\
\hline \multirow{4}{*}{$\begin{array}{l}\text { Kepuasan_Peng } \\
\text { guna }\end{array}$} & KP1 & 0,666 & 0,5 & 0,78 \\
\hline & KP2 & 0,7 & & \\
\hline & KP3 & 0,693 & & \\
\hline & KP4 & 0,697 & & \\
\hline \multirow[t]{9}{*}{ KualitasSistem } & $\mathrm{KS} 1 *$ & 0,613 & 0,4 & 0,88 \\
\hline & KS2 & 0,686 & & \\
\hline & $\mathrm{KS} 3$ & 0,724 & & \\
\hline & KS4 & 0,699 & & \\
\hline & KS5 & 0,694 & & \\
\hline & KS6 & 0,701 & & \\
\hline & KS7 & 0,644 & & \\
\hline & KS8 & 0,687 & & \\
\hline & $\mathrm{KS} 9 *$ & 0,599 & & \\
\hline Pengembangan & PP1 & 0,691 & 0,5 & 0,79 \\
\hline \multirow[t]{3}{*}{ Penggunaan } & PP2 & 0,698 & & \\
\hline & PP3 & 0,675 & & \\
\hline & PP4 & 0,728 & & \\
\hline
\end{tabular}

Note: * Indikator yang akan dihapus

Analisis discriminant validity adalah analisis yang menilai sejauh mana suatu konstruk benar-benar berbeda dari konstruk lainnya. Validitas dari setiap konstruk sudah baik dengan ditunjukkan nilai estimasi pada Tabel $4<$ nilai AVE Tabel 3 . 
Tabel 4. Covarian Correlation

\begin{tabular}{|c|c|c|c|c|}
\hline \multicolumn{2}{|c|}{ Covarian Correlation } & \multirow{2}{*}{$\begin{array}{r}\text { Esti } \\
\text { mate }\end{array}$} & \multirow{2}{*}{$\frac{\text { S.E. }}{, 026}$} & \multirow{2}{*}{$\frac{\text { C.R. }}{6,090}$} \\
\hline KualitasInformasi & KualitasLayanan & & & \\
\hline KualitasInformasi & KualitasSistem & 184 & ,027 & 6,711 \\
\hline KualitasInformasi & Kepuasan_Pengguna & 155 & ,023 & 6,633 \\
\hline KualitasInformasi & $\begin{array}{l}\text { Pengembangan_Peng } \\
\text { gunaan }\end{array}$ &, 157 & ,024 & 6,537 \\
\hline KualitasInformasi & Individual_Benefit & ,132 & ,021 & 6,207 \\
\hline KualitasLayanan & KualitasSistem & ,176 & ,028 & 6,358 \\
\hline KualitasLayanan & Kepuasan_Pengguna & , 165 & ,025 & 6,541 \\
\hline KualitasLayanan & $\begin{array}{l}\text { Pengembangan_Peng } \\
\text { gunaan }\end{array}$ & ,153 & ,024 & 6,249 \\
\hline KualitasLayanan & Individual_Benefit &, 156 & ,024 & 6,477 \\
\hline KualitasSistem & Kepuasan_Pengguna & ,163 & ,024 & 6,761 \\
\hline KualitasSistem & $\begin{array}{l}\text { Pengembangan_Peng } \\
\text { gunaan }\end{array}$ & ,167 & ,025 & 6,710 \\
\hline KualitasSistem & Individual_Benefit & ,148 & ,023 & 6,562 \\
\hline $\begin{array}{l}\text { Kepuasan_Penggun } \\
\text { a }\end{array}$ & $\begin{array}{l}\text { Pengembangan_Peng } \\
\text { gunaan }\end{array}$ &, 171 & ,024 & 7,162 \\
\hline $\begin{array}{l}\text { Kepuasan_Penggun } \\
\text { a }\end{array}$ & Individual_Benefit &, 140 &, 021 & 6,807 \\
\hline $\begin{array}{l}\text { Pengembangan_Pe } \\
\text { nggunaan }\end{array}$ & Individual_Benefit & , 148 & ,022 & 6,841 \\
\hline
\end{tabular}

\subsection{Analisis Struktur Model (SEM)}

Model yang akan diteliti dan dilankan dalam AMOS ditunjukkan oleh pada Gambar 4 di bawah ini. Untuk memenuhi kecocokan model hasil dari factor loading Model Delone tidak boleh mengalami perubahan lebih dari 0,01 dari factor loading CFA, memiliki AVE $>0,5$, dan CR $>0,7$. Hasil perhitungan AMOS menunjukkan kesesuaian pada semua kriteria factor loading, AVE, dan CR.

Analisis model fit dilakukan untuk menganalisis model apakah sesuai dengan penelitian atau di tolak. Beberapa indikator untuk menilai bahwa model sesuai dengan data antara lain: Chi square : df (degree of freedom), GFI(good fit index), NFI(normed fit index), CFI(comparative fit index), TLI(non-normed fit index), RSMEA(Root Mean Square Error of Approximation), RMR (root mean square residual), dan Hoelter. Dari Tabel 5 diketahui bahwa 7 dari 9 indikator menunjukkan kesesuaian model yang baik. Indikator GFI menurut Sharma [32], konsensus saat ini tidak menggunakan langkah-langkah GFI ini, sedangkan indikator NFI menurut David [33] tidak direkomendasikan. Sehingga dapat dikatakan bahwa model didukung atau sesuai dengan data penelitian.

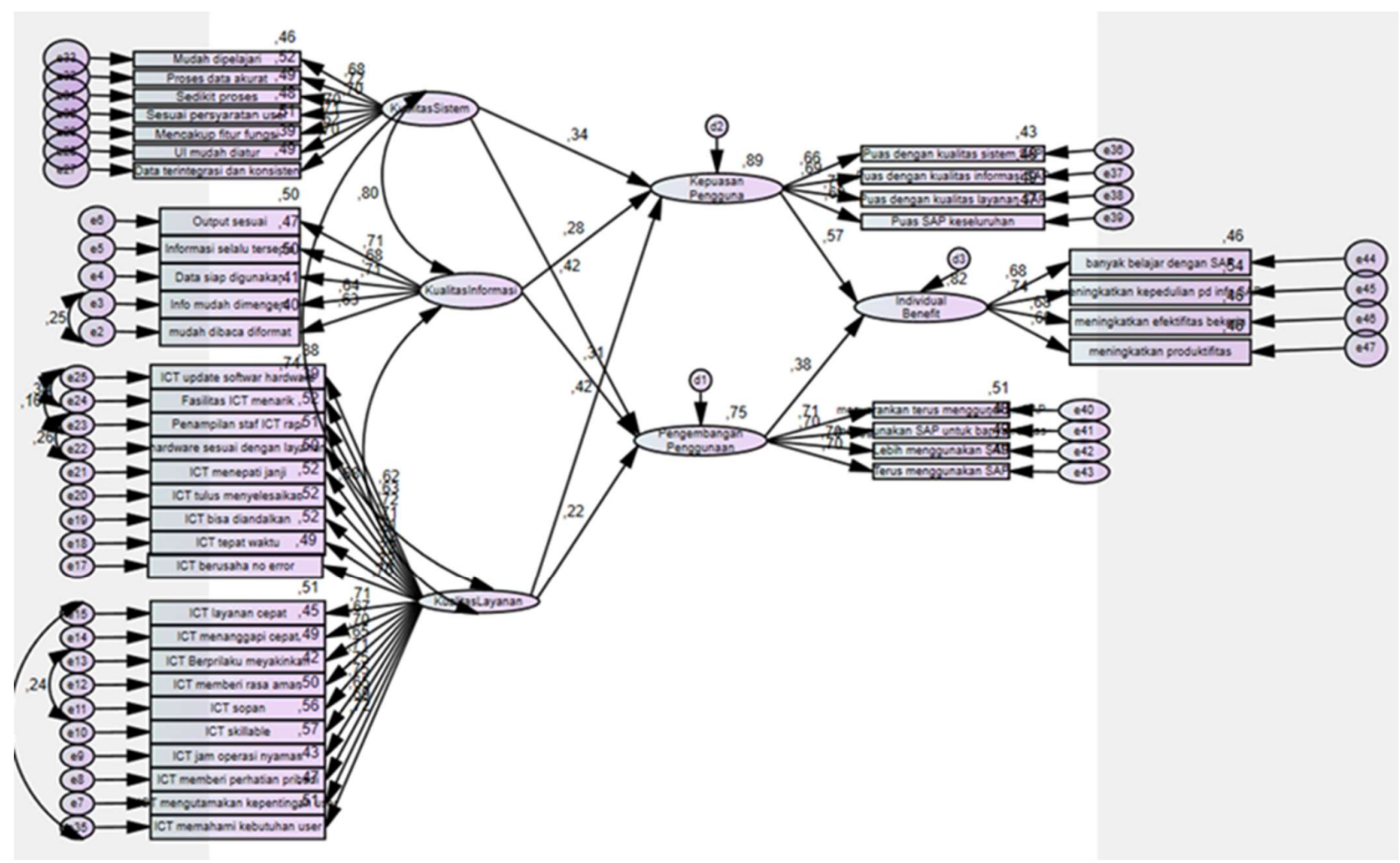

Gambar 4. Perhitungan Bobot dengan AMOS 
Tabel 5. Good of Fit Indikator

\begin{tabular}{|c|c|c|c|c|}
\hline $\begin{array}{l}\text { GOF (Good } \\
\text { of Fit) }\end{array}$ & Constrain & $\begin{array}{l}\text { DeLone \& } \\
\text { McLean } \\
\text { Model }\end{array}$ & $\begin{array}{l}\text { CFA } \\
\text { Model }\end{array}$ & Indikator \\
\hline chi-square & & 1112,490 & 1062,910 & \\
\hline \multicolumn{5}{|l|}{$\left(\chi^{2}\right)$} \\
\hline $\begin{array}{l}\text { Degrees of } \\
\text { freedom }\end{array}$ & & 843 & 840 & \\
\hline Probability & $<0,05$ & 0,000 & 0,000 & Good \\
\hline \multicolumn{5}{|l|}{ square $(\chi 2)$} \\
\hline GFI & $>90$ &, 830 &, 837 & Poor \\
\hline NFI & $>90$ & 823 & ,830 & Poor \\
\hline TLI & $>90$ & ,946 & ,955 & Good \\
\hline CFI & $>90$ & ,950 & ,958 & Good \\
\hline RMSEA & $<0,05$ &, 037 &, 033 & Good \\
\hline RMR & $<0,05$ &, 022 &, 021 & Good \\
\hline Hoelter & $>75$ & $181-187$ & $204-211$ & Good \\
\hline
\end{tabular}

Selanjutnya adalah path analisis, dimana model secara teoritis dievaluasi dengan mengidentifikasi masing-masing hubungan yang dihipotesiskan dalam diagram jalur (Hn). Adapun hasil perhitungan path analisis dengan AMOS ditunjukkan oleh Gambar 4. atau Tabel 6. di bawah ini.

Tabel 6. Hasil Hipotesis Path AMOS

\begin{tabular}{lccc}
\hline Hipotesis & $\begin{array}{r}\text { Std } \\
\text { Estimate }\end{array}$ & $\begin{array}{r}\text { C.R. (t- } \\
\text { val) }\end{array}$ & P \\
\hline $\begin{array}{l}\text { (H3b) Kepuasan_Pengguna }> \\
\begin{array}{l}\text { KualitasSistem } \\
\text { (H3a) Pengembangan_Penggunaan }>\end{array}\end{array}$ &, 335 & 3,053 &, 002 \\
$\begin{array}{l}\text { KualitasSistem } \\
\text { (H5b) Kepuasan_Pengguna }>\end{array}$ &, 28 & 3,251 &, 001 \\
$\begin{array}{l}\text { KualitasInformasi } \\
\text { (H4b) Kepuasan_Pengguna }>\end{array}$ &, 422 & 5,127 &, 001 \\
$\begin{array}{l}\text { KualitasLayanan } \\
\text { (H5a) Pengembangan_Penggunaan }>\end{array}$ &, 31 & 2,657 &, 008 \\
$\begin{array}{l}\text { KualitasInformasi } \\
\text { (H4a) Pengembangan_Penggunaan }>\end{array}$ &, 22 & 2,579 &, 010 \\
$\begin{array}{l}\text { KualitasLayanan } \\
\text { (H2) Individual_Benefit }>\end{array}$ &, 571 & 4,280 &, 001 \\
$\begin{array}{l}\text { Kepuasan_Pengguna } \\
\text { (H1)Individual_Benefit }>\end{array}$ &, 377 & 2,943 &, 003 \\
\hline \begin{tabular}{l} 
Pengembangan_Penggunaan \\
\hline
\end{tabular} & & &
\end{tabular}

Dari hasil perhitungan dengan AMOS pada Tabel 6. dan Gambar 4. di atas, menunjukkan semua hasil hipotesis didukung oleh data. Hipotesis pertama (H1) didukung oleh data, yang berarti terdapat hubungan positif antara Pengembangan Penggunaan ERP SAP terhadap manfaat individu pengguna (bobot $=0,377, \mathrm{t}=2,943$, dan $\mathrm{p}$ $=, 003)$ diterima. Hipotesis kedua $(\mathrm{H} 2)$ didukung oleh data, yang berarti terdapat hubungan positif antara kepuasan pengguna terhadap manfaat individu pengguna (bobot $=, 571, \mathrm{t}=4,280, \mathrm{p}=, 001$ ) diterima.

Selanjutnya adalah hipotesis dari variabel bebas dimana hipotesis tiga a (H3a) didukung oleh data, yang berarti kualitas sistem ERP SAP yang lebih baik berpengaruh positif terhadap tingkat pengembangan penggunaan (bobot $=, 417, t=3,251$, dan $\mathrm{p}=, 001$ ) diterima. Hipotesis tiga $\mathrm{b}(\mathrm{H} 3 \mathrm{~b}$ ) didukung oleh data, yang berarti kualitas sistem ERP SAP yang lebih baik berpengaruh positif terhadap tingkat kepuasan pengguna yang lebih tinggi (bobot $=, 335, \mathrm{t}=3,053, \mathrm{p}=, 002$ ) diterima. Hipotesis empat a (H4a) didukung oleh data, yang berarti kualitas layanan sistem ERP yang lebih baik berpengaruh positif terhadap pengembangan penggunaan ( $b o b o t=, 22, t=2,579, p=, 010$ ) diterima. Hipotesis empat $\mathrm{b}(\mathrm{H} 4 \mathrm{~b})$ didukung oleh data, yang berarti kualitas layanan sistem ERP yang lebih baik berpengaruh positif terhadap tingkat kepuasan pengguna yang lebih tinggi (bobot $=, 422$, $\mathrm{t}=\quad 5,127, \mathrm{p}=, 001)$ diterima. Hipotesis lima a (H5a) didukung oleh data, yang berarti kualitas informasi ERP SAP yang lebih tinggi berpengaruh positif terhadap tingkat penggunaan yang lebih tinggi ( bobot $=, 31, \mathrm{t}=2,657, \mathrm{p}=, 008)$ diterima. Yang terakhir adalah hipotesis lima $\mathrm{b}(\mathrm{H} 5 \mathrm{~b})$ didukung oleh data, yang berarti kualitas informasi ERP SAP yang lebih tinggi berpengaruh positif terhadap tingkat kepuasan pengguna yang lebih tinggi (bobot $=, 28, \mathrm{t}=2,771$, $\mathrm{p}=$,006) diterima.

\section{PEMBAHASAN}

\subsection{H1 Terdapat Hubungan Positif antara Pengembangan Penggunaan ERP SAP Terhadap Manfaat Individu Pengguna}

Hipotesis ini didukung oleh nilai bobot estimasi path yang ditunjukkan oleh Tabel 6 . bernilai 0,342 yang berarti nilai kontribusi variabel pengembangan penggunaan yang mendukung variabel individual benefit. Selain itu dukungan hipotesis ini juga ditunjukkan oleh Tabel 2. dimana nilai rata-rata variabel pengembangan penggunaan SAP bernilai 4,07 atau bisa dikatakan bahwa pengguna ERP SAP di Perusahaan setuju telah melakukan pengembangan penggunaan sistem SAP sebanding dengan nilai rata-rata variabel individual benefit yang bernilai 4,05. Hasil penelitain ini juga sesuai dengan penelitian yang dilakukan oleh Hsu dan Roki $[5,10]$ bahwa pengembangan penggunaan secara signifikan memiliki hubungan positif terhadap manfaat individu pengguna. Hal tersebut merupakan kewajaran karena Perusahaan telah mengimplementasikan sistem ERP SAP sejak tahun 2008 atau lebih dari 10 tahun. Selain itu dengan melakukan pengembangan pengembangan maka secara otomatis kemampunan individu karyawan juga meningkat.

\subsection{H2 Terdapat Hubungan Positif antara Kepuasan Pengguna Terhadap Manfaat Individu Pengguna}

Hipotesis ini didukung oleh nilai bobot estimasi path yang yang bernilai 0,562 yang berarti nilai kontribusi variabel kepuasan pengguna yang mendukung variabel individual benefit. Selain itu dukungan hipotesis ini juga ditunjukkan oleh nilai rata-rata variabel kepuasan pengguna ERP SAP bernilai 4,07 sebanding dengan nilai rata-rata variabel individual benefit yang bernilai 4,05 atau bisa dikatakan bahwa pengguna ERP SAP di Perusahaan setuju telah puas terhadap sistem ERP SAP sehingga karyawan setuju telah mendapatkan individual benefit. Kepuasan pengguna ini didukung oleh fakta bahwa selama lebih dari 10 tahun, karyawan Perusahaan sangat terbantu dengan sistem ERP SAP dan tidak ada resistensi yang ditunjukkan oleh pengguna dalam menjalankan sistem ERP SAP ini. Hasil penelitain ini juga sesuai dengan penelitian yang dilakukan oleh 
Hsu [5], bahwa kepuasan pengguna secara signifikan memiliki hubungan positif terhadap manfaat individu pengguna.

\subsection{H3a Kualitas Sistem ERP SAP yang Lebih Baik Berpengaruh Positif Terhadap Tingkat Pengembangan Penggunaan}

Hipotesis ini didukung oleh nilai bobot estimasi path yang signifikan secara statistik bernilai 0,374 yang berarti nilai kontribusi variabel kualitas sistem ERP SAP mendukung variabel pengembangan penggunaan. Selain itu dukungan hipotesis ini juga ditunjukkan oleh nilai rata-rata variabel kualitas sistem ERP SAP bernilai 4,04 sebanding dengan nilai rata-rata variabel pengembangan penggunaan yang bernilai 4,07 atau bisa dikatakan bahwa responden setuju bahwa kualitas sistem ERP SAP baik sehingga karyawan setuju untuk melakukan pengembangan penggunaan. sesuai dengan penelitian yang dilakukan oleh Hsu dan Ifinedo $[5,11]$ bahwa kualitas sistem secara positif memberikan dampak signifikan pada pengembangan penggunaan.

\subsection{H3b Kualitas Sistem ERP SAP yang Lebih Baik Berpengaruh Positif Terhadap Tingkat Kepuasan Pengguna yang Lebih Tinggi}

Hipotesis ini didukung oleh nilai bobot estimasi path yang signifikan secara statistik bernilai 0,277 merupakan nilai kontribusi variabel kualitas sistem ERP SAP terhadap variabel kepuasan pengguna. Selain itu dukungan hipotesis ini juga ditunjukkan oleh nilai rata-rata variabel kualitas sistem ERP SAP bernilai 4,04 sebanding dengan nilai rata-rata variabel kepuasan pengguna yang bernilai 4,07 atau bisa dikatakan bahwa responden setuju bahwa kualitas sistem ERP SAP baik, sehingga karyawan puas dengan sistem ERP SAP. Kualitas sistem ERP SAP ini didukung fakta bahawa pada 2018 SAP memiliki lebih dari 95.000 pelanggan di lebih dari 120 negara. Artinya banyak pengguna di seluruh dunia puas dengan kualitas sistem ERP SAP sehingga meningkatkan jumlah penggunanya. Berdasarkan teori model keberhasilan D\&M IS [12] dan penelitian sebelumnya [28, 29, 27] menunjukkan hubungan positif antara kualitas sistem dan kepuasan pengguna.

\subsection{H4a Kualitas Layanan Sistem ERP yang Lebih Baik Berpengaruh Positif Terhadap Pengembangan Penggunaan}

Hipotesis ini didukung oleh nilai bobot estimasi path yang signifikan secara statistik bernilai 0,195 yang berarti nilai kontribusi variabel kualitas layanan yang diberikan departemen ICT mendukung variabel pengembangan penggunaan. Selain itu dukungan hipotesis ini juga ditunjukkan nilai rata-rata variabel kualitas layanan bernilai 3,92 hampir sebanding dengan nilai rata-rata variabel pengembangan penggunaan dengan bernilai 4,07 atau bisa dikatakan bahwa responden setuju bahwa kualitas layanan Departemen ICT SAP cukup baik sehingga karyawan bisa melakukan pengembangan penggunaan dengan baik. sesuai dengan penelitian yang dilakukan oleh Ifinedo dan Hsu $[5,11]$ bahwa kualitas layanan secara positif memberikan dampak signifikan pada pengembangan penggunaan. Sehingga dengan adanya kualitas layanan ERP SAP yang baik maka akan membuat karyawan Perusahaan dapat mengeksplorasi lebih jauh terhadap sistem bahkan membuat inovasi-inovasi berupa aplikasi turunan dari ERP SAP ini.

\subsection{H4b Kualitas Layanan Sistem ERP yang Lebih Baik Berpengaruh Positif Terhadap Tingkat Kepuasan Pengguna yang Lebih Tinggi}

Hipotesis ini didukung oleh nilai bobot estimasi path yang signifikan secara statistik bernilai 0,344 merupakan nilai kontribusi variabel kualitas layanan ERP SAP terhadap variabel kepuasan pengguna. Selain itu dukungan hipotesis ini juga ditunjukkan oleh nilai rata-rata variabel kualitas layanan ERP SAP bernilai 3,92 sebanding dengan nilai rata-rata variabel kepuasan pengguna yang bernilai 4,07 atau bisa dikatakan bahwa responden setuju bahwa kualitas layanan ERP SAP yang diberikan oleh Departemen ICT sudah baik, sehingga membuat karyawan puas dengan sistem ERP SAP. Hal ini didukung oleh teori yang menyatakan bahwa layanan yang diberikan oleh personel SI (Karyawan layanan sistem informasi) tidak secara langsung menandakan kualitas sistem ERP itu sendiri $[30,31]$.

\subsection{H5a Kualitas Informasi ERP SAP yang Lebih Tinggi Berpengaruh Positif Terhadap Tingkat Pengembangan Penggunaan yang Lebih Tinggi}

Hipotesis ini didukung oleh nilai bobot estimasi path yang signifikan secara statistik bernilai 0,279 yang berarti nilai kontribusi variabel kualitas informasi mendukung variabel pengembangan penggunaan. Selain itu dukungan hipotesis ini juga ditunjukkan oleh nilai rata-rata variabel kualitas informasi bernilai 4,06 sebanding dengan nilai ratarata variabel pengembangan penggunaan dengan bernilai 4,07 atau bisa dikatakan bahwa responden setuju bahwa kualitas informasi ERP SAP baik sehingga karyawan bisa melakukan pengembangan penggunaan dengan baik. Ketika pengguna melihat bahwa informasi itu akurat, diperbarui, konsisten, relevan, lengkap, dan formatnya mudah dimengerti, itu akan mengarahkan mereka ke tingkat penggunaan yang lebih tinggi dan tingkat kepuasan yang lebih tinggi [5].

\subsection{H5b Kualitas Informasi ERP SAP yang Lebih Tinggi Berpengaruh Positif Terhadap Tingkat Kepuasan Pengguna yang Lebih Tinggi}

Hipotesis ini didukung oleh nilai bobot estimasi path yang signifikan secara statistik bernilai 0,232 merupakan nilai kontribusi variabel kualitas informasi ERP SAP terhadap variabel kepuasan pengguna. Selain itu dukungan hipotesis ini juga ditunjukkan oleh nilai rata-rata variabel kualitas informasi ERP SAP bernilai 4,06 sebanding dengan nilai rata-rata variabel kepuasan pengguna yang bernilai 4,07 atau bisa dikatakan bahwa responden setuju bahwa kualitas informasi ERP SAP sudah baik, sehingga membuat karyawan puas dengan sistem ERP SAP. Secara logika ketika indikator variabel tersebut baik akan mempengaruhi kepuasan pengguna yang baik, begitu juga sebaliknya. Sesuai dengan penelitian yang dilakukan oleh Rocky [10] dan Hsu [5] 
bahwa kualitas informasi akan secara positif memberikan dampak signifikan pada kepuasan pengguna.

\section{KESIMPULAN}

Tujuan awal dari penelitian ini adalah untuk melakukan pengujian pada teori model DeLone and McLean Information System Success model pada implementasi ERP SAP di Perusahaan. Oleh karena itu dibuatlah sebuah framework yang mengacu pada model DeLone and McLean Information System Success model untuk dilakukan pengujian pada data responden karyawan Perusahaan manufaktur ini. Hasil yang diperoleh dari penelitian ini adalah model yang diajukan dalam penelitian sesuai dengan data dan kondisi di Perusahaan manufaktur ini. Kemudian dari 8 hipotesis yang diajukan, menghasilkan semua variabel memiliki hubungan yang signifikan terhadap manfaat individu. Oleh karena itu dari penelitian ini disarankan perusahaan khususnya Perusahaan yang diteliti ini perlu memperhatikan information quality (kualitas informasi), system quality (kualitas sistem), service quality (kualitas layanan), extended use (pengembangan penggunaan), dan user satisfactory (kepuasan user) untuk dapat meningkatkan individual benefit (manfaat individu) dan pada akhirnya akan memberikan keuntungan untuk organisasi yang merupakan tujuan utama dari manajemen menggunaka sistem ERP SAP ini.

Hasil penelitian memberikan beberapa implikasi untuk dunia Sistem Informasi khususnya untuk manejemen, menajer, manajer ICT, dan para peneliti lainnya. Pertama bagi manajemen temuan dalam penelitian ini dapat dijadikan sebagai rujukan bahwa sistem ERP SAP yang baik dapat meningkatkan manfaat individual dimana secara tidak langsung juga akan meningkatkan keuntungan perusahaan. Kedua bagi manager, model D\&M dengan modifikasi ini dapat digunakan oleh manajer yang berniat untuk mewujudkan efektivitas operasional dan strategis dari sistem ERP yang diterapkan melalui penguatan manfaat individu karyawan. Kemudian untuk manajer ICT perlu pemahaman bahwa salah satu faktor yang mempengaruhi kinerja individu karyawan adalaha layanan mereka, sehingga manajer ICT perlu mengevaluasi dan meningkatkan layanan yang menjadi indikator kepuasan layana. Ketiga, untuk peneliti selanjutnya hasil penelitian ini bisa jadi dasar untuk landasan penelitian selanjutnya yang berlaku pada industri sejenis atau konsep sejenis.

Untuk penelitian berikutnya perlu menambah variabel eksogen maupun variabel endogen dan juga indikator pada setiap variabel sehingga dapat diketahui factor lain untuk menganalisis sukses faktor suatu sistem informasi dan kesesuaian model yang dihasilkan semakin baik. Selain itu penelitian selanjutnya perlu memperluas objek penelitian bukan hanya skala satu perusahaan namun lebih luas pada skala industri yang memilik persamaan. Dan terakhir Penelitian selanjutnya diharapkan untuk menambah jumlah sampel yang digunakan agar hasil penlitian lebih akurat dan relevan.

\section{DAFTAR PUSTAKA}

[1] L. Kenneth C dan . J. P, Laudon Management Information Systems Managing the Digital Firm THIRTEENTH EDITION, England: Pearson., 2014.

[2] L. M. Hitt, D. Wu dan X. Zhou, "ERP Investment: Business Impact and Productivity Measures," Research Gate, 2011.

[3] G. Gable dan D. Sedera, "Reconceptualizing information system success: The IS-impact measurement model," Journal of the Association for Information Systems, 2008.

[4] C. Retting, "The trouble with Enterprise software," MIT Sloan Management Review, pp. 20-27, 2007.

[5] P.-F. Hsu, R. Y. HsiuJu dan J.-C. Chung, “Assessing ERP PostImplementation Success at the Individual Level: Revisiting the Role of Service Quality,” National Tsing Hua University, 2015.

[6] Y. Wang dan Y. Liao, "ssessing eGovernment systems success: A validation of the DeLone and McLean model of information systems success," Government Information Quarterly, 2008.

[7] J. S. Park dan H. H. Yang, "Perceived absorptive capacity of individual users in performance of Enterprise Resource Planning (ERP) usage: The case for Korean firms," Information \& Management, vol. 3, no. 44, pp. 300-312, 2007.

[8] S. Lee dan J. Yuu, Success model of project management information system in construction Development of an electronic Portfolio system success model: An information systems approach, Automation in Construction, 2012, pp. 8293.

[9] C. Bossen, L. Groth dan F. Jensen, "Evaluation of a comprehensive EHR based on the DeLone and McLean model for IS success: Approach, results, and success factors," International journal of medical informatics, vol. 82, p. 940 953, 2013.

[10] H. Roky dan Y. Al Meriouh, "Evaluation by users of an industrial information system (XPPS) based on the DeLone and McLean model for IS success," ScienceDirect, 2015.

[11] P. Ifinedo, B. Rapp dan K. Sunberg, "Relationships among ERP post-implementation success constructs: An analysis at the organizational level," Elsevier, 2010.

[12] W. H. Delone dan E. R. Mclean, "The DeLone and McLean Model of Information Systems Success: A Ten-Year Update," Journal of Management Information Systems, vol. 19, pp. 9-30, 2003.

[13] C. V. Brown, D. W. Dehayes, J. A. Hoffer dan E. W. Martin, Managing Information Technology, Seventh Edition, New Jersey: Prentice Hall, 2015.

[14] T. Wailgum, "Why ERP systems are more important than ever.," CIO Web site, 29 January 2008. [Online]. Available: www.cio.com/article/print/177300. [Diakses 2 July 2019].

[15] P. Cocca, F. Marciano, D. Rossi dan M. Alberti, "Business Software Offer for Industri 4.0: the SAP case,” Elsevier, 2018. 
[16] W. Holsapple, Y. Wang dan J. Wu, "Empirically testing user characteristics and fitness factors in Enterprise Resource Planning success," International Journal of Human-Computer Interaction, pp. 325-342, 2003.

[17] L. M. Given, The Sage encyclopedia of qualitative research methods, California: SAGE Publication, 2008.

[18] M. Saunders, P. Lewis dan A. Thornhill, Research Methods for Business Students (6th ed.), Pearson, 2012.

[19] J. F. Hair Jr., W. C. Black, B. J. Babin dan R. E. Anderson, Multivariate Data Analysis, Seventh Edition, Edinburgh Gate: Pearson, 2014.

[20] P. J. Rosenberg, "What is the minimum sample size needed to conduct the SEM analysis utilizing AMOS software?," ResearchGate, 2015. [Online]. Available: https://www.researchgate.net/post/What is the minimum_sa mple size needed to conduct the SEM analysis utilizing AMOS_software. [Diakses 10 September 2019].

[21] P. Lowry dan J. Gaskin, "Partial Least Squares (PLS) Structural Equation Modeling (SEM) for Building and Testing Behavioral Causal Theory: When to Choose It and How to Use It.," IEEE Transactions on Professional Communication, p. 123-146, 2014.

[22] U. Sekaran dan R. Bogie, Research Methods for Business 7th Edition, Chichester: John Wiley, 2016.

[23] Abdillah, Willy dan J. Hartono, Partial Least Square (PLS) Alternatif Structural Equation Modeling (SEM) Dalam Penelitian Bisnis, Yogyakarta, 2015.

[24] A. Burton-Jones dan D. W. Straub Jr, "Reconceptualizing system usage: An approach and empirical test," Information systems research, pp. 228-246, 2006.

[25] J. Hsieh dan W. Wang, "Explaining employees' extended use of complex information systems.," European Journal of Information Systems, pp. 216-227, 2007.

[26] P. Kotler, Marketing management: Analysis, planning, implementation and control, Englewoods Cliff,New Jersey: Prentice Hall, 1997.

[27] P. Seddon, "A respecification and extension of the DeLone and McLean model of IS success," Information Systems Research, pp. 240-253, 1997.

[28] C. M. Chiu, C. S. Chiu dan H. C. Chang, "Examining the integrated influence of fairness and quality on learner's satisfaction and web-based learning continuance intention," Information Systems Journal, pp. 271-287, 2007.

[29] L. Halawi, R. McCarthy dan J. E. Aronson, "An empirical investigation of knowledge management systems' success," Journal of Computer Information Systems, pp. 121-135, 2007.

[30] N. Gorla, T. Somers dan B. Wong, "Organizational impact of system quality, information quality, and service quality," Journal of Strategic Information Systems, pp. 207-228, 2007.

[31] E. Wang dan J. Chen, "Effects of internal support and consultant quality on the consulting process and ERP system quality," Decision Support Systems, pp. 1029-1041, 2006.

[32] S. Sharma, S. Mukherjee, A. Kumar dan W. Kumar, "A simulation study to investigate the use of cutoff values for assessing model fit in covariance structure models., Journal of Business Research, pp. 935-943, 2005.

[33] David, "Measuring Model Fit," davidakenny, 24 November 2015. [Online]. Available: http://davidakenny.net/cm/fit.htm. [Diakses 20 November 2019].

\section{BIODATA PENULIS}

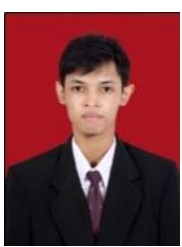

Mochamad Rizky Ilmawan

Penulis adalah Alumni Magister Management di Fakultas Ekonomi Universitas Andalas.

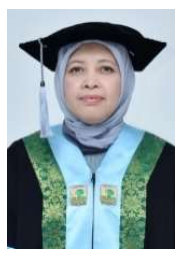

Vera Pujani

Penulis adalah staf pengajar di Fakultas Ekonomi Universitas Andalas. Riset yang pernah dilakukan terkait dengan E-Business, E-commerce, Small Business, Website. 